\section{Water Stress Patterns of Xerophytic Plants in an Urban Landscape}

\author{
Richard Martinson ${ }^{1}$ and John Lambrinos \\ Department of Horticulture, Oregon State University, 4017 Agricultural and \\ Life Sciences Building, Corvallis, OR 97331-7304
}

Ricardo Mata-González

Department of Animal and Rangeland Sciences, 112 Withycombe Hall, Oregon State University, Corvallis, OR 97331

Additional index words. urban landscapes, xeric, native plants, water budgeting, water potential

\begin{abstract}
Efficient water use in urban landscapes is a common objective throughout the western United States. Vegetative species promoted for their drought tolerance characteristics are often included in landscapes designed for resource conservation. However, water requirements of most common landscape species have not been quantified. This is especially true for xerophytic species. This lack of landscape plant water requirement data is a significant constraint on the design of efficient irrigation systems and management practices affecting urban landscape water use. Current irrigation practices often fail to consider the unique physiology of xerophytic species, and irrigation scheduling models may not be appropriate for xeric landscapes using xerophytic vegetation as the primary method of reducing water use. This work describes the seasonal patterns of growth and xylem water status for four regionally native xeric shrub species planted in an unirrigated urban landscape in the semi-arid environment of central Oregon. The four species (Artemisia tridentata, Holodiscus microphyllus, Ericameria nauseosa, and Ribes cereum) exhibited substantial growth over the course of 18 months without irrigation in a heavily modified urban soil profile. Water potential of the four species was strongly correlated with surface $(10 \mathrm{~cm})$ soil moisture $(r \geq 0.90)$, less so with reference monthly evapotranspiration $(r \leq 0.55)$, and only weakly with water vapor deficit (r $\leq 0.22)$. In $A$. tridentata and $H$. microphyllus, xylem water potential became more negative during the growing season and tracked the seasonal decline in soil moisture. In contrast, the xylem water potential of $E$. nauseosa and $R$. cereum tracked soil moisture early in the season but became less responsive to soil moisture in the driest months, suggesting different drought adaptation strategies in these species. Three of the four species showed no visual signs of drought stress and maintained acceptable aesthetics even as soil moisture decreased to less than $10 \%$. However, $R$. cereum exhibited a drought dormancy strategy that made it less aesthetically desirable. These results suggest that extreme xerophytic shrubs provide an opportunity for significant reductions in water use in urban landscapes.
\end{abstract}

Many urban centers in the western United States are in ecoregions that experience generally low or markedly seasonal patterns of precipitation that create prolonged periods of soil water deficits during the year (Omernik, 2014). As a result, most urban landscapes in the region use seasonal irrigation to maintain plant health and aesthetics. However, urban water use has become contentious. In the western United States, $50 \%$ to $60 \%$ of residential water is used for outdoor purposes, predominantly urban landscapes (City of Bend, 2011; Mini et al., 2014; St. Hilaire et al., 2008). Consequently, regional public policy has often targeted outdoor water use in urban landscapes as a significant tool for reducing overall municipal water use (English et al., 2002; Glenn et al.,

Received for publication 15 Aug. 2018. Accepted for publication 3 Feb. 2019.

1Corresponding author. E-mail: martinsr@oregonstate. edu. site is unique in its ability to provide these elements.
One approach to reducing the water footprint of urban landscapes is using more species that have unique adaptations for tolerating extended periods of water stress. These species could be used to design landscapes that provide a range of functions such as aesthetics, but that also have very low or even no irrigation requirements. For example, many perennial shrubs native to arid regions of the western United States have extreme drought adaptations that allow them to thrive even in habitats that experience extreme water deficit (Smith et al., 1997).

A roadblock to designing landscapes with extremely low water input is our generally limited understanding of how xeric-adapted species respond to declining water availability. In addition, the few data that exist generally come from field studies of plants in minimally disturbed natural habitats (Ehleringer et al., 1991; Mata-González et al., 2014; Volo et al., 2014; Webb et al., 1978). Urban contexts likely pose a unique set of environmental challenges that could interfere with the drought adaptations of xerophyte species. For example, urban soils are often compacted or have more restrictive soil volumes relative to rural or wildland soils (Craul, 1991). Compacted soils can negatively affect root growth and reduce the water-holding capacity of soils (Benbough et al., 2005; Eavis, 1972; Sims and Singh, 1978). Almost no data describe the ecophysiological response of xerophytic species in actual urban landscapes. This lack of information makes it difficult to develop appropriate plant palettes and appropriate recommendations for their management.

In this study, we evaluated the drought response of xerophytic plant species in an established urban landscape designed to emulate the ecological functions of a sagebrush steppe plant association in the East Cascades Slopes and Foothills ecoregion. The landscape was designed to meet the water conservation standards under the Living Building Challenge, and it was actively used by the landowners during the course of the study. We measured the water status and growth patterns of four native shrub species, and we tested the association between xylem water potential, monthly evapotranspiration (ET), soil moisture level, and vapor pressure deficit (VPD). We also subjectively evaluated the aesthetic quality of the species through interviews with the property owners.

\section{Materials and Methods}

Study site. We conducted the study at Desert Rain, a residence and demonstration site located in the urban core of Bend, OR (lat. $44^{\circ} 3^{\prime} 10.87^{\prime \prime} \mathrm{N}$, long. $121^{\circ} 19^{\prime} 17.67^{\prime \prime} \mathrm{W}$ ) (Fig. 1). Bend is a city of $\approx 80,000$ that is located in the East Cascades ecoregion (Omernik 2014) at an elevation of $1115 \mathrm{~m}$. The climate is semiarid (Fig. 2). Summers are typically warm and dry, with an average daytime temperature of $25^{\circ} \mathrm{C}$ (June-September). Winters are normally cold, with annual precipitation falling as rain or snow. The average winter daytime temperature 


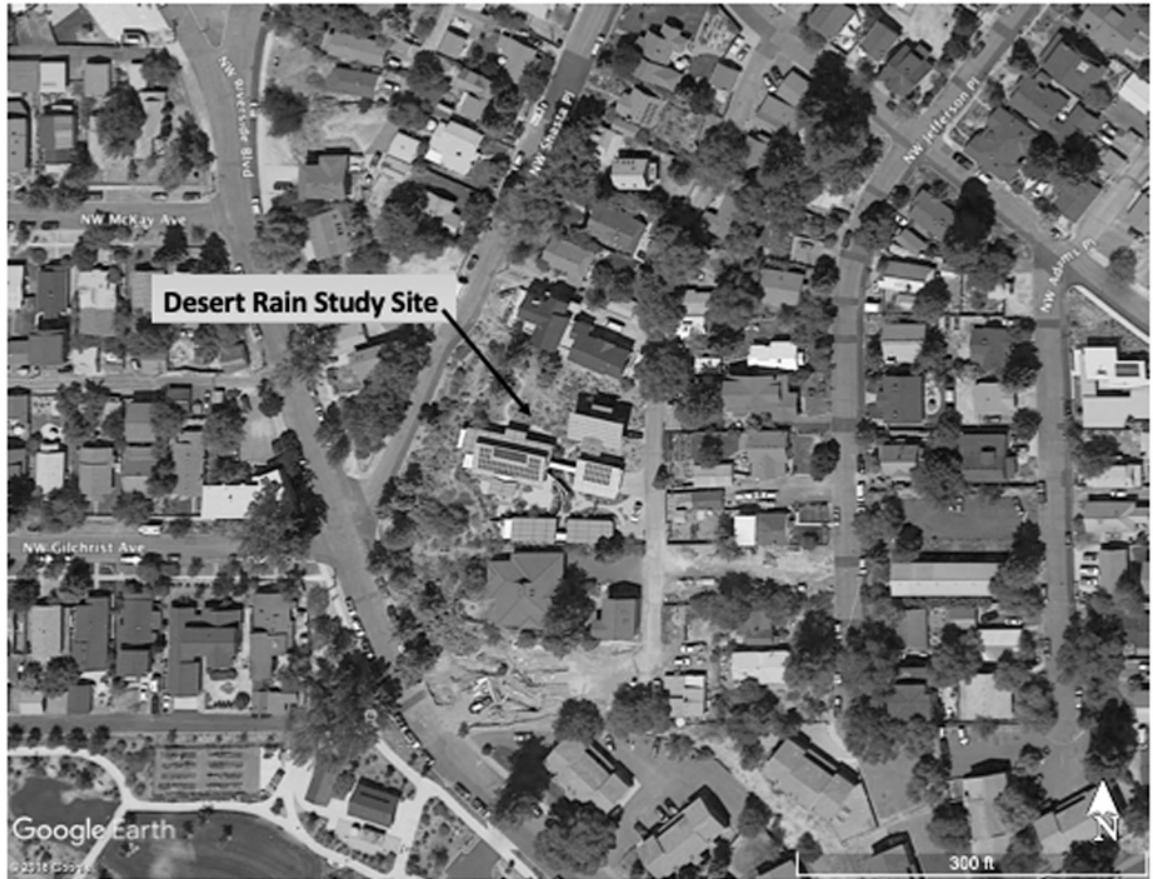

Fig. 1. Study site location showing the urban setting within the city of Bend, OR (lat. $44^{\circ} 3^{\prime} 10.87^{\prime \prime} \mathrm{N}$, long. $\left.121^{\circ} 19^{\prime} 17.67^{\prime \prime} \mathrm{W}\right)$.

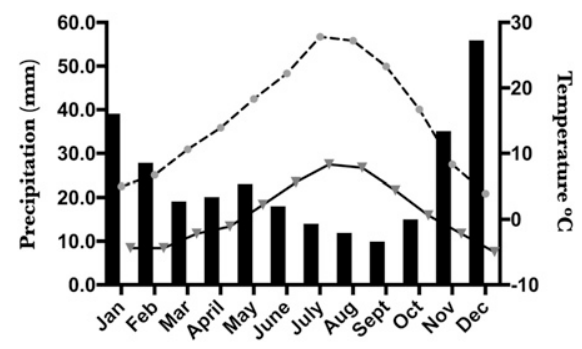

Fig. 2. Climograph for Bend, OR. Mean monthly precipitation (bars), mean daily high temperature (dotted line), and mean daily low temperature (solid line) are historical averages (1954-2015).

is $6{ }^{\circ} \mathrm{C}$ (November-February). The average annual precipitation is $289 \mathrm{~mm}$.

Dominant soils at the study site are the Wanoga (35\%) and Fremkle (30\%) series Vitrixerands of the order Andisols, described as moderately deep, well-drained sandy loam on volcanic uplands (Natural Resources Conservation Service, 2014) containing an average $60 \%$ ash in the upper $35-60 \mathrm{~cm}$ and a high humus content in the surface horizon (Krasilnikov, 2009). The mean annual soil temperature is $7.2{ }^{\circ} \mathrm{C}$. The remaining soils are classified as Rock Outcrop (Natural Resources Conservation Service, 2014). The slope varies from $0 \%$ to $20 \%$ in the study area, with north/northwest aspect predominance.

The study landscape covers $\approx 168 \mathrm{~m}^{2}$, which is approximately $5 \%$ of the entire property. The design intent was to emulate the structural and vegetative components of the sagebrush steppe plant association that is characteristic of the site while enhancing the aesthetic considerations typical of a managed urban landscape. Construction in- cluded the creation of rock outcrops, drainage patterns, and spatial distribution of plants to create spatially patchy zones of elevated resources known as resource islands; these comprise a critical structural and functional component of sagebrush steppe communities (Halvorson et al., 1994). The study portion of the landscape was unirrigated. No irrigation system was installed, nor has the study site received supplemental irrigation. The overall designed landscape at the site included 38 native plant species representing a range of functional forms, including 12 shrub species, 22 forbs, and 4 species of grasses.

Study plants. Four shrub species native to the East Cascades ecoregion were used for this study: Artemisia tridentata Nutt ssp. wyomingensis Beetle \& Young (ARTRW8), Holodiscus microphyllus (prev. dumosus) var. glabrescens (HODU), Ericameria nauseosa (Pall. Ex Pursh), G.L. Nesom \& Baird (ERNA10), and Ribes cereum Douglas var. cereum (RICE) (Natural Resources Conservation Service, 2006). All four species are associated with dry habitats and are occasionally used as ornamentals with low water requirements (CalFlora, 2018). All plants were propagated locally from propagules collected within the same East Cascades ecoregion as the study site (Omernik, 2014), and they were planted as 1-gallon nursery stock. Each individual plant was inoculated with a commercially available endo-ecto mycorrhizal inoculant (Mycorrhizal Applications, Grants Pass, OR) and watered once during landscape construction.

Ten months after the landscape was planted, we identified four target individuals of each species for study. Each individual was located in the same soil and microclimate conditions and within $5 \mathrm{~m}$ of an installed weather station.
Physical measurements. In Aug. 2015, we installed a HoboWare model U30 weather station datalogger (Onset Computer Corporation, Bourne, MA) at the study site. The station was situated within $5 \mathrm{~m}$ of the study plants. We used the station to record volumetric soil water at $10-\mathrm{cm}, 30-\mathrm{cm}$, and $60-\mathrm{cm}$ depths with dielectric aquameter probes (Onset Computer Corporation, Bourne, MA), precipitation, and ambient air temperature. Readings were collected every $5 \mathrm{~min}$ and averaged every $2 \mathrm{~h}$, resulting in 12 records every $24 \mathrm{~h}$.

To assess possible changes in soil structure resulting from construction activities, we measured soil bulk density and porosity from samples collected at the study site and from a relatively undisturbed reference site within the same East Cascades ecoregion and soil series (lat. $44^{\circ} 0^{\prime} 53.29^{\prime \prime} \mathrm{N}$, long. $121^{\circ} 17^{\prime} 14.80^{\prime \prime} \mathrm{W}$ ). The same ecological site type is reported for both the study and reference site. The dominant plant association for both sites is Juniperus occidentalis Hook/Pinus ponderosa Lawson \& C. Lawson/Festuca idahoensis Elmer spp. idahoensis (Natural Resources Conservation Service, 2014). Soil samples at both sites were collected across a depth profile using an AMS Bulk Density Soil Sampling Kit (AMS, Inc. American Falls, ID). Samples were taken at $10-\mathrm{cm}, 30-\mathrm{cm}$, and $60-\mathrm{cm}$ depths at the reference site and $10-\mathrm{cm}$ and $30-\mathrm{cm}$ depths at the study site. Samples from the $60-\mathrm{cm}$ depth were unattainable at the study site due to shallow bedrock. Ten $90.59-\mathrm{cm}^{3}$ samples were collected for each depth at the study site and the reference site. We estimated gravimetric soil moisture content by weighing samples at field capacity, drying each sample in a microwave for three cycles of $5 \mathrm{~min}$, and weighing the dried samples. We estimated soil bulk density by dividing the dry soil weight by volume and soil porosity according to the method of Thien and Graveel (2002).

Reference evapotranspiration. We obtained average monthly reference evapotranspiration $\left(\mathrm{ET}_{r e f}\right)$ from the AgriMet Cooperative Agricultural Weather Network (Palmer 2008) calculated for the Bend, OR station (lat. $44^{\circ} 2^{\prime} 5.0^{\prime \prime} \mathrm{N}$, long. $121^{\circ} 19^{\prime} 12.972^{\prime \prime} \mathrm{W}$, elevation: $1103 \mathrm{~m}$ ) located $0.62 \mathrm{~km}$ south of the study property. Calculations used the ASCE standard Penman-Monteith model (2013). We estimated the maximum midday vapor pressure deficit $\left(\mathrm{VPD}_{\mathrm{d}}\right)$ following the method of Murray (1967), with saturated vapor pressure estimates calculated following the method of Jensen et al. (1990).

Plant performance. We measured monthly mid-day xylem water potential $(\Psi)$ for each target individual using a model $1505 \mathrm{D}$ pressure chamber (PMS Instrument Company, Albany, OR). Five replicated measurements were performed for each individual plant during each sample period. Measurements throughout the study period were performed for the same individual plants. A similar approach using comparable levels of individual replication has been used to measure in situ water potential in other landscape ornamental plants (Nardini et al., 2015; Sjöman et al., 2018). 
We estimated the change in the aboveground biomass of the target individuals over the course of 18 months because they were planted in the landscape. Because removing entire plants from the created landscape was not approved by the property owner, we estimated the aboveground biomass of the established target plants using the reference unit technique (Bonham, 2013). We destructively harvested a representative $10 \%$ sample of the canopy of each target individual. The representative samples were dried, weighed, and used to estimate the aboveground biomass of whole plants by extrapolation (Evans et al., 2013). Because we did not have initial size estimates of the nursery stock when it was planted in the landscape, we established an initial baseline using comparable nursery stock. This stock was the same size [1.0 gallon $(3.8 \mathrm{~L})]$ and grown in the same nursery under the same conditions as the stock planted in the landscape. We destructively sampled 10 individuals representative of this reference nursery stock. All aboveground biomass was removed, dried at $116^{\circ} \mathrm{C}$ for $48 \mathrm{~h}$, and weighed.

We assessed the rooting depth of each target individual by excavating root systems of individual plants to a depth of $60 \mathrm{~cm}$, when possible. Excavation of deeper soil layers was inhibited by the shallow parent material characteristic of the study site. We traced tap and fibrous roots back to the crown of the plant to ensure that measurements were for the correct species. Roots extending beyond $60-\mathrm{cm}$ depths were noted.

Aesthetic quality. Plant health and aesthetic quality were qualitatively assessed by the lead author and the homeowners. Owners were informally interviewed twice per month regarding perceived landscape health and visual quality.

Statistical analysis. We described the associations between monthly xylem pressure and volumetric soil water content at each measured depth using the Pearson correlation. The same method was used to test the association between monthly xylem pressure with $\mathrm{ET}_{r e f}$ and VPD. We tested whether soil properties across the depth profile at the study and reference sites differed from each other using a two-way analysis of variance. Statistical tests were conducted using GraphPad Prism version 7.0 (GraphPad Software, La Jolla, CA).

\section{Results}

Patterns of plant water stress. The xylem water potential of $A$. tridentata and $H$. dumosus became more negative over the summer in relation to the spring, and it continued to have a sharp decline during the fall. The water potential of $R$. cereum and E. nauseosa also became more negative over the summer with respect to the spring, but the decline during the fall was not as pronounced. Ribes cereum and E. nauseosa also had generally less negative xylem water potential during the season than $A$. tridentata and $H$. dumosus (Fig. 3). The xylem water potential of the four species was strongly correlated with soil moisture content at all three depths, but primarily at the shallower layers (Table 1). However, the water potential of both $A$. tridentata and $H$. dumosus more closely tracked the seasonal decline in soil moisture than did $R$. cereum or E. nauseosa (Fig. 3). The xylem water potential was only weakly correlated with $\mathrm{ET}_{r e f}$ and $\mathrm{VPD}_{\mathrm{d}}$ in all four species (Table 1). $\mathrm{ET}_{\text {ref }}$ reached its maximum observed levels in early summer and then declined over the next 4 months (Fig. 4)

Plant growth and health. Significant biomass production was recorded for all four study species after 18 months of growth. Each shrub had an aboveground biomass ranging from 5.1 to $14.1 \mathrm{~g}$ when planted and exhibited production rates from $400 \%$ to $1200 \%$ (Table 2). The rooting depth for each individual plant exceeded $60 \mathrm{~cm}$ within 18 months.

Aesthetic quality. Three of the study species, Artemisia tridentata, H. dumosus, and E. nauseosa, did not exhibit any visual indicators of drought stress and retained their aesthetic value throughout the growing season, even as volumetric soil moisture declined to less than $10 \%$. In contrast, $R$. cereum dropped much of its leaves during late summer and displayed signs characteristic of a summer deciduous strategy for surviving drought. Generally, the homeowners were very pleased with the visual quality and apparent health of the landscape and the rapid growth of the plants. However, they did express concern about the visual stress of the Ribes in August and September.

Soil characteristics. Soil characteristics at the study site were generally similar to those at a nearby reference site (Table 3 ). There were no significant site or site $\times$ depth interaction effects for any of the measured soil variables $(P>0.1)$.

\section{Discussion}

The species examined in this study exhibited the ability to tolerate extended periods of drought. Despite receiving no supplemental irrigation, all four species established and grew substantially over 18 months. This ability likely reflects a range of morphological adaptations as well as isohydric and anisohydric responses that are typical of many perennials from this ecozone. These adaptations include modified leaf morphology, extensive or deep root systems, and various forms of drought dormancy (Chaves et al., 2003). All four species displayed rapid root growth exceeding a $60-\mathrm{cm}$ depth within
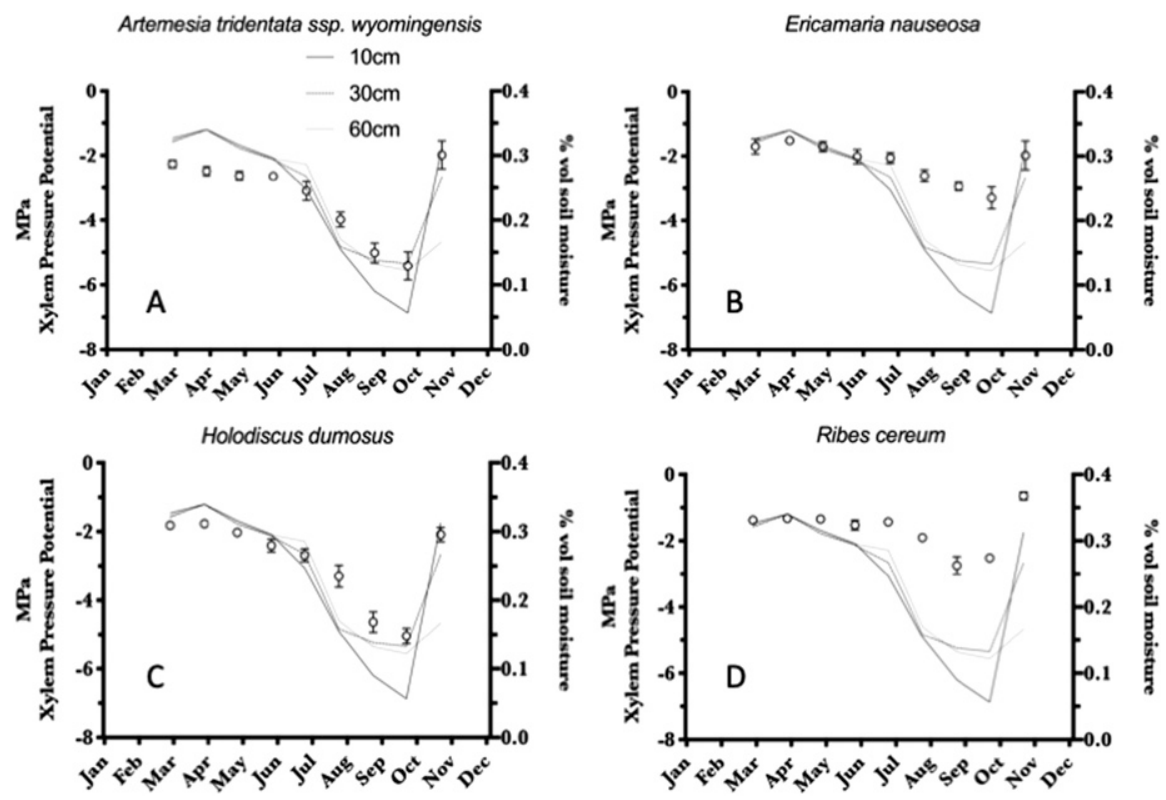

Fig. 3. Monthly xylem water potential (open circles) over the course of 1 year for four xerophyte plant species in an urban residential landscape in Bend, OR: (A) Artemisia tridentata; (B) Ericameria nauseosa; (C) Holodiscus dumosus; and (D) Ribes cereum. Volumetric soil moisture values at 10, 30, and $60 \mathrm{~cm}$ are plotted as lines.

Table 1. Degree of correlation between measured xylem water potential, monthly cumulative reference evapotranspiration $\left(\mathrm{ET}_{r e f}\right)$, and mean daily vapor pressure deficit $\left(\mathrm{VPD}_{\mathrm{d}}\right)$ for four xerophyte plant species in an urban residential landscape in Bend, OR. ${ }^{\mathrm{z}}$

\begin{tabular}{lccccc}
\hline \multicolumn{5}{c}{ Pearson correlations } \\
\hline Water potential & $10 \mathrm{~cm}$ & $30 \mathrm{~cm}$ & $60 \mathrm{~cm}$ & $\mathrm{ET}_{\text {ref }}$ & $\mathrm{VPD}_{\mathrm{d}}$ \\
\hline ARTRW8 & 0.98 & 0.92 & 0.74 & -0.55 & -0.14 \\
ERNA10 & 0.98 & 0.97 & 0.88 & -0.52 & -0.22 \\
RICE & 0.90 & 0.80 & 0.56 & -0.52 & -0.09 \\
HODU & 0.99 & 0.94 & 0.82 & -0.52 & -0.18 \\
\hline
\end{tabular}

${ }^{\mathrm{z}}$ Values are Pearson correlation coefficients. ARTRW8 $=$ Artemisia tridentata ssp. wyomingensis ERNA10 = Ericameria nauseosa $;$ RICE $=$ Ribes cereum; HODU = Holodiscus dumosus. 

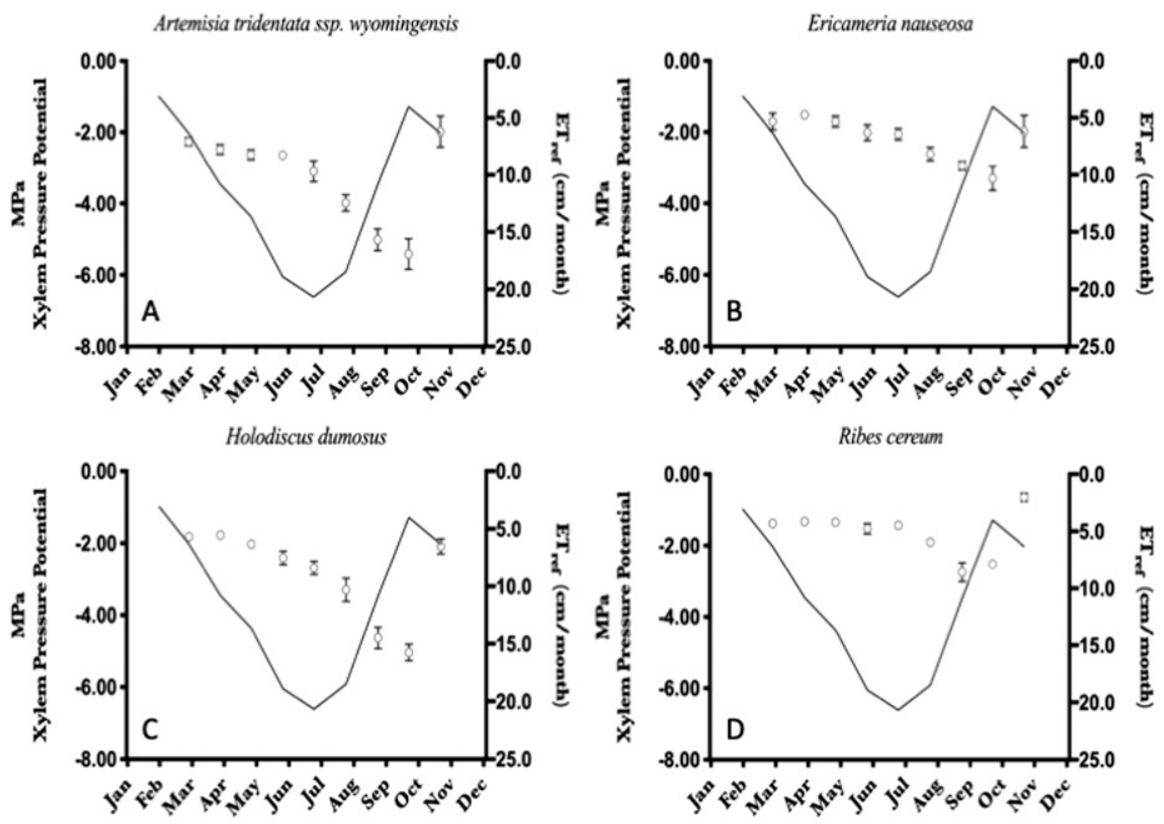

Fig. 4. Monthly xylem water potential (dots) over the course of 1 year for four xerophyte plant species in an urban residential landscape in Bend, OR: (A) Artemisia tridentata; (B) Ericameria nauseosa; (C) Holodiscus dumosus; and (D) Ribes cereum. The solid line indicates the 2004-16 historic mean of monthly cumulative reference evapotranspiration $\left(\mathrm{ET}_{r e f}\right)$.

Table 2. Estimated change in aboveground biomass ( $\mathrm{g}$ ) of four xerophyte plant species over 18 mo. planted in an unirrigated urban residential landscape in Bend, OR. Biomass estimates are presented for the replicated $10 \%$ reference unit and the derived total plant estimate. ${ }^{\mathrm{z}}$

\begin{tabular}{lcccc}
\hline \multicolumn{5}{c}{ Change in aboveground biomass } \\
\hline Species & Reference unit $(\mathrm{g})$ & Total plant $(\mathrm{g})$ & Nursery stock, 1-gallon $(\mathrm{g})$ & Increase (\%) \\
\hline ARTRW8 & $6.6 \pm 0.1$ & 66.25 & $5.13 \pm 0.2$ & 1,191 \\
ERNA10 & $7.6 \pm 0.4$ & 75.55 & $14.13 \pm 0.9$ & 434 \\
RICE & $7.1 \pm 0.5$ & 70.50 & $6.38 \pm 0.4$ & 1,005 \\
HODU & $6.0 \pm 0.2$ & 60.03 & $5.38 \pm 0.4$ & 1,020 \\
\hline
\end{tabular}

${ }^{\mathrm{z}}$ Values are means $\pm \mathrm{SD}(\mathrm{n}=4)$. HODU $=$ Holodiscus dumosus; ERNA10 $=$ Ericameria nauseosa ARTRW8 = Artemisia tridentata ssp. wyomingensis $;$ RICE $=$ Ribes cereum .

Table 3. Representative soil properties across a depth profile $(10-60 \mathrm{~cm})$ at an urban residential study site in Bend, OR (Desert Rain) and a nearby undisturbed reference site (reference site). ${ }^{\mathrm{z}}$

\begin{tabular}{|c|c|c|c|c|c|c|}
\hline & \multicolumn{2}{|c|}{$10 \mathrm{~cm}$} & \multicolumn{2}{|c|}{$30 \mathrm{~cm}$} & \multicolumn{2}{|c|}{$60 \mathrm{~cm}$} \\
\hline & Study site & Reference site & Study site & Reference site & Study site & Reference site \\
\hline Bulk density $\left(\mathrm{g} \cdot \mathrm{cm}^{-3}\right)$ & $1.05 \pm 0.19$ & $1.04 \pm 0.07$ & $1.27 \pm 0.23$ & $1.23 \pm 0.04$ & - & $1.39 \pm 0.13$ \\
\hline Soil porosity $(\%)$ & $0.60 \pm 0.07$ & $0.61 \pm 0.03$ & $0.52 \pm 0.09$ & $0.54 \pm 0.02$ & - & $0.47 \pm 0.05$ \\
\hline
\end{tabular}

1 year of planting, surpassing the 15 - to $30-\mathrm{cm}$ average rooting depth commonly seen in nonxerophyte landscape ornamentals (St. Hilaire et al., 2008). Roots of the target individuals were even observed penetrating small cracks in the underlying bedrock.

There were also marked differences in the drought responses of the four study species. Artemisia tridentata, Holodiscus dumosus, and Ericameria nauseosa exhibited no visual indication of drought stress and retained their aesthetic value even as volumetric soil moisture declined to less than $10 \%$. In contrast, Ribes cereum exhibited marked drought dormancy, losing most of its leaves during late summer and early autumn.

Landscape water requirement. Such drought tolerance adaptations are likely a main reason why the seasonal pattern of xylem water potential and visual indicators of water stress did not track $\mathrm{ET}_{r e f}$ or $\mathrm{VPD}_{\mathrm{d}}$. This lack of correlation between plant water demand and $\mathrm{ET}_{r e f}$ complicates efforts to estimate the irrigation demand of a landscape (Kjelgren, 2016). Most currently available tools for estimating the landscape water demand are modified versions of models that were originally developed for estimating crop water requirements in agricultural systems (Farag et al., 2011; Gober et al., 2011; Nouri et al., 2013). These models assume that water demand and evapotranspiration are closely correlated. A typical approach estimates water demand as a fractional proportion of $\mathrm{ET}_{r e f}$. The proportion is estimated using adjustment factors to account for species differences in water demand as well as a range of other processes and factors, such as microclimate, soil cover, and the stage of plant growth that potentially modify water flux from the landscape (Grabow et al., 2013; Pannkuk et al., 2010; Radwan et al., 2010). Although earlier approaches often included a large number of adjustment factors, more recent approaches such as the Simplified Landscape Irrigation Demand Estimator (SLIDE) use only a small number of plant factors to estimate water demand (Kjelgren, 2016). However, the suitability of ET-based approaches for estimating the water demand of xeric vegetation is questionable (Mata-González et al., 2005). The extreme morphological and physiological adaptations to water stress that these species exhibit are likely not fully accounted for in the $\mathrm{ET}_{r e f}$ adjustment factors used in landscape irrigation models (Ferguson, 1987; Mata-González et al., 2005; Smith and Smith, 2013).

We estimated the water demand for our study landscape using three widely available irrigation scheduling models: 1) EPA WaterSense New Home Specifications (EPA, 2014), 2) Hunter Run-Time Calculator (Hunter Industries, 2018), and 3) The Simplified Landscape Irrigation Demand Estimator (SLIDE) (Kjelgren, 2016). These models were selected because of their accessibility (e.g., online availability) and their wide acceptance in the landscape industry. Each model is based on $\mathrm{ET}_{\text {ref }}$ but uses different speciesspecific adjustment values. Models also differ regarding the type and number of adjustment factors related to other parameters such as vegetation density. We parameterized the models based on 0.1 ha of landscaped area at the study site. Details and summary model calculations are available elsewhere (Martinson, 2018). The three different models provided estimates of the landscape water demand that ranged from $336.9 \mathrm{~m}^{3} /$ season for WaterSense to 79.5 $\mathrm{m}^{3} /$ season for Hunter and $61.52 \mathrm{~m}^{3} /$ season for SLIDE. The different results largely reflect the water demand relative to $\mathrm{ET}_{r e f}$ that each model estimated for xerophytic vegetation. Differences in water demand estimates across various models have been shown to largely reflect differences in plant-specific or landscape-specific adjustment factors for $\mathrm{ET}_{\text {ref }}($ Kjelgren et al., 2015). The results of our study suggest that even the low water demand estimates provided by existing models may overestimate the demand for many extreme xerophyte species.

A significant constraint to improving estimates made by water demand models is the lack of empirical data to parameterize them. However, ongoing research is beginning to provide empirical estimates of water use for common landscape types and species, at least for regions with Mediterraneantype climates (Reid and Oki, 2008, 2016; Snyder and Ackley, 2015).

Urban landscapes. In created urban landscapes, severe disturbances associated with construction activities can alter conditions such as exposure, soil compaction and chemistry, wind patterns, hydrologic function, and biotic 
communities, resulting in highly modified environments (Craul, 1991; Lorenz and Lal, 2009). Altered conditions could interfere with xerophyte drought adaptations. For example, increases in soil bulk density can negatively affect root growth through the rhizosphere by reducing pore space and the ability of soil to hold plant-accessible moisture (Benbough et al., 2005). However, the species in this study performed similarly to those in less disturbed contexts. The rooting depth of the study species during the first year was deep, despite the shallow soils and rocky substrate. All study species developed fibrous roots exceeding $50 \mathrm{~cm}$, consistently accessing higher moisture levels at greater depths than normally expected in urban landscapes or designed for in urban irrigation systems. These rooting depths were similar to those that have been observed for other xeric-adapted species in undisturbed natural landscapes in the Owens Valley of California (MataGonzález et al., 2014). This might be a primary reason why the study species performed so well. Another reason is that soils at the study site were very similar to those of a nearby reference site; however, soils at the study site were shallower. Although bulk density has been shown to increase at construction sites (Evanylo et al., 2016), we found no statistically significant differences in bulk density between the study site and the reference site.

The specific construction techniques used at the study site might be a reason for the relatively low bulk density. Site construction included extensive subsurface excavation for infrastructure unique to a Living Futures residence. The extent of the excavation exceeded levels commonly associated with residential construction and may have decreased soil organic matter while mitigating soil compaction. Another mitigating factor was that the study site landscape was designed to emulate the structural and spatial characteristics of reference communities. The landscape included a diverse and purposely chosen association of plant functional types that included grasses and forbs. The physical facilitation and spatial patterning of these different components are known to be critically important to the ecological function of plant associations in semi-arid environments (Jackson and Caldwell, 1993). Results of this study suggest that designing and constructing urban landscapes in ways that emulate the species composition and structural patterning of less disturbed xeric plant communities may result in similar functional aspects and ecological processes, such as hydraulic lift and nutrient cycling, that will result in reduced water use requirements for landscapes.

Summary. Xerophyte species can be a suitable landscape choice in arid and semi-arid environments, and even in urban residential landscapes. However, current landscape management approaches will need to be adjusted to achieve the maximum water-savings benefit from their use. Current water demand models can overestimate water demand in instances when there is little correlation between plant water demand and $\mathrm{ET}_{r e f}$ for xerophyte species. Furthermore, conventional landscape management assumes an average shrub rooting depth of $15-30 \mathrm{~cm}$ (St. Hilaire et al., 2008), and models developed to encourage irrigation efficiency are based on average rooting depths, soil characteristics, and application efficiency of the irrigation system (Connellan, 2013; Ferguson, 1987; Irrigation Association, 2014; Jensen et al., 2016; Nouri et al., 2013; White, 2013). A constraint to developing better management guidelines for xerophyte species is that few studies have described their drought physiology in the context of ornamental landscapes. Additional work is needed to quantify the drought stress response of most landscape species, most notably species with aesthetic values and physiobiochemical adaptations that can contribute to a significant reduction in water use in urban landscapes.

\section{Literature Cited}

Benbough, A.G., M.F. Bransby, J. Hans, S.J. McKenna, T.J. Roberts, and T.A. Valentine. 2005. Root responses to soil physical conditions; growth dynamics from field to cell. J. Expt. Bot. 57(2):437-447.

Bonham, C.D. 2013. Measurements for terrestrial vegetation. 2nd ed. Wiley-Blackwell.

Calflora. 2018. Berkeley, California. 11 Jan. 2019. $<$ Calflora.org $>$.

Chaves, M.M., J.P. Maroco, and J.S. Pereira. 2003. Understanding plant response to drought - from genes to whole plant. Funct. Plant Biol. 30(3):239-264.

City of Bend. 2011. Water management and conservation plan. Department of Public Works, Bend, OR.

Connellan, G. 2013. Water use efficiency for irrigated turf and landscape. CSIRO, Collingwood VIC, Australia.

Craul, P.J. 1991. Urban soils: Problems and promise. Arnoldia 51(1):23-32.

Eavis, B.W. 1972. Soil physical conditions affecting seedling root growth. Plant Soil 36(1-3):613-622.

Ehleringer, J.R., S.L. Phillips, W.S.F. Schuster, and D.R. Sandquist. 1991. Differential utilization of summer rains by desert plants. Oecologia 88(3):430-434.

English, M.J., K.H. Solomon, and G.J. Hoffman. 2002. A paradigm shift in irrigation management. J. Irrig. Drain. Eng. 128(5).

EPA. 2014. WaterSEnse water budget approach, 1.02 .

Evans, T.L., R. Mata-Gonzalez, D.W. Martin, T. McLendon, and J.S. Noller. 2013. Growth, water productivity, and biomass allocation of Great Basin plants as affected by summer watering. Ecohydrology 6(5):713-721.

Evanylo, G.K., S.N. Porta, J. Li, D. Shan, J.M Goatley, and R. Maguire. 2016. Compost practices for improving soil properties and turfgrass establishment and quality on a disturbed urban soil. Compost Sci. Util. 24(2):136-145.

Farag, F.A., C.M.U. Neale, R.K. Kjelgren, and J. Endter-Wada. 2011. Quantifying urban landscape water conservation potential using high resolution remote sensing and GIS. Photogramm. Eng. Remote Sensing 77(11):1113-1122.

Ferguson, B.K. 1987. Water conservation methods in urban landscape irrigation: An exploratory overview. JAWRA Journal of the American Water Resources Association 23(1):147-152.
Glenn, D.T., J. Endter-Wada, R. Kjelgren, and C.M.U. Neale. 2015. Tools for evaluating and monitoring effectiveness of urban landscape water conservation interventions and programs. Landsc. Urban Plan. 139:82-93.

Gober, P., E.A. Wentz, T. Lant, M.K. Tschudi, and C.W. Kirkwood. 2011. WaterSim: A simulation model for urban water planning in Phoenix, Arizona, USA. Environ. Plann. B Plann. Des. 38(2):197-215.

Grabow, G.L., I.E. Ghali, R.L. Huffman, G.L. Miller, D. Bowman, and A. Vasanth. 2013. Water application efficiency and adequacy of ET-based and soil moisture-based irrigation controllers for turfgrass irrigation. J. Irrig. Drain. Eng. 139(2):113-123.

Halvorson, J.J., H. Bolton, Jr., J.L. Smith, and R.E. Rossi. 1994. Geostatistical analysis of resource islands under Artemisia tridentata in the shrubsteppe. Great Basin Nat. 54:313-328.

Hayden, L., M.L. Cadenasso, D. Haver, and L.R. Oki. 2015. Residential landscape aesthetics and water conservation best management practices: Homeowner perceptions and preferences. Urban Planning 144

Hunter Industries. 2018. Hunter: Residential \& commercial irrigation. 13 July 2018. $<$ Hunterindustries.com $>$.

Jackson, R.B. and M.M. Caldwell. 1993. The scale of nutrient heterogeneity around individual plants and its quantification with geostatistics. Ecology 74(2):612-614.

Jensen, Marvin E. and R.G. Allen (eds.). 2016. Evaporation, evapotranspiration, and irrigation Water Requirements. 2nd ed. American Society of Civil Engineers, Reston, VA.

Kjelgren, R. 2016. Simple landscape irrigation demand estimation: Slide rules. Plants, Soils, and Climate Faculty Publications, Paper 771.

Kjelgren, R., R.C. Beeson, D. Pittenger, and T. Montague. 2015. Simple landscape irrigation demand estimation: Slide rules. Appl. Eng. Agr. 32(4):363-378.

Krasilnikov, P.V. 2009. A handbook of soil terminology, correlation and classification. Earthscan, London, Sterling VA.

Lorenz, K. and R. Lal. 2009. Biogeochemical $\mathrm{C}$ and $\mathrm{N}$ cycles in urban soils. Environ. Intl. 35(1):1-8.

Martinson, R. 2018. Water efficiency for urban landscapes in semi-arid environments. Oregon State University, unpublished $\mathrm{PhD}$ thesis.

Mata-González, R., T.L. Evans, D.W. Martin, T. McLendon, J.S. Noller, C. Wan, and R.E. Sosebee. 2014. Patterns of water use by Great Basin plant species under summer watering. Arid Land Res. Mgt. 28(4):428-446.

Mata-González, R., T. McLendon, and D.W. Martin. 2005. The inappropriate use of crop transpiration coefficients $(\mathrm{Kc})$ to estimate evapotranspiration in arid ecosystems: A review. Arid Land Res. Mgt. 19(3):285-295.

McLennan, J.F. 2008. Pursuit of true sustainability in the built environment. V1.3. Cascadia Green Building Council, Seattle, WA.

Mini, C., T.S. Hogue, and S. Pincetl. 2014. Estimation of residential outdoor water use in Los Angeles, California. Landsc. Urban Plan. 127:124-135.

Murray, F.W. 1967. On the computation of saturation vapor pressure. J. Appl. Meteorol. 6:203-204.

Nardini, A., V. Casolo, A. Dal Borgo, T. Savi, B. Stenni, and P. Bertoncin. 2015. Rooting depth, water relations and non-structural carbohydrate dynamics in three woody angiosperms differentially affected by an extreme summer drought. Plant Cell Environ. 39(3):618-627.

Natural Resources Conservation Service. 2006. The PLANTS Database. $<$ http://plants.usda.gov/>. 
Natural Resources Conservation Service. 2014. Web soil survey. 12 Mar. 2014. <www. websoilsurvey.sc.egov.usda.gov $>$.

Nouri, H., S. Beecham, A.M. Hassanli, and F. Kazemi. 2013. Water requirements of urban landscape plants: A comparison of three factor-based approaches. Ecol. Eng. 57:276-284.

Omernik, J.M.G.E.G. 2014. Ecoregions of the conterminous United States: Evolution of a hierarchical spatial framework. Environ. Mgt. 54(6):1249-1266.

Palmer, P.L. 2008. AGRIMET: Automated Weather Observations for Evapotranspiration Modeling, in Western Snow Conference, Pacific Northwest Region, Boise, ID.

Pannkuk, T.R., R.H. White, K. Steinke, J.A. Aitkenhead-Peterson, D.R. Chalmers, and J.C. Thomas. 2010. Landscape coefficients for single- and mixed-species landscapes. HortScience 45:1529-1533.

Qaiser, K., S. Ahmad, W. Johnson, and J. Batista. 2011. Evaluating the impact of water conservation on fate of outdoor water use: A study in an arid region. J. Environ. Mgt. 92(8):2061-2068.

Radwan, A.A., M.N. El Awady, M.M. Hegazy, and S.A. Mohamed. 2010. Determining plant water use and landscape coefficients of selected nurs- ery and landscape plants. Misr J. Ag. Eng. 27(2):521-529.

Reid, K. and L.R. Oki. 2016. Evaluation of ornamental plant performance on four deficit irrigation levels: Working with industry to promote sustainable plant choices for summerdry regions, in International Society for Horticultural Science (ISHS), Leuven, Belgium, 155-162.

Reid, S.K. and L.R. Oki. 2008. Field trials identify more native plants suited to urban landscaping. Calif. Agr. 62(3):97-104.

Sims, P.L. and J.S. Singh. 1978. The structure and function of ten western North American grasslands: II. Intra-seasonal dynamics in primary producer compartments. J. Ecol. 66(2): 547-572.

Sjöman, H., A. Hiron, and N.L. Bassuk. 2018. Improving confidence in tree species selection for challenging urban sites: A role for leaf turgor loss. Urban Ecosyst. 21(6):11711188.

Smith, M.M. and S.W. Smith. 2013. Agricultural/ urban/environmental water sharing in the western United States: Can engineers engage social science for successful solutions? Irrig. Drain. 62(3):289-296.
Smith, S.D., R.K. Monson, and J.E. Anderson. 1997. Physiological ecology of North American desert plants. Springer, New York.

Snyder, R.L. and D. Ackley. 2015. Advance in ET-based landscape irrigation management. Agr. Water Mgt. 147(1):187-197.

St. Hilaire, R., M.A. Arnold, D.C. Wilkerson, D.A. Devitt, B.H. Hurd, B.J. Lesikar, V.I. Lohr, C.A. Martin, G.V. McDonald, R.L. Morris, D.R. Pittenger, D.A. Shaw, and D.F. Zoldoske. 2008. Efficient water use in residential urban landscapes. HortScience 43:2081-2092.

Thien, S.J. and J.G. Graveel. 2002. Laboratory manual for soil science. McGraw-Hill Science/ Engineering/Math.

Volo, T.J., E.R. Vivoni, C.A. Martin, S. Earl, and B.L. Ruddell. 2014. Modelling soil moisture, water partitioning, and plant water stress under irrigated conditions in desert urban areas. Ecohydrology 7(5):1297-1313.

Webb, W., S. Szarek, W. Lauenroth, R. Kinerson, and M. Smith. 1978. Primary productivity and water use in native forest, grassland, and desert ecosystems. Ecology 59(6):1239-1247.

White, R. 2013. A fundamental basis for efficient lawn and landscape irrigation, Texas A\&M University. 